\title{
Lupus tumidus
}

\section{Postać obrzękowa tocznia rumieniowatego}

\author{
Julia Nowowiejska, Anna Baran, Julita A. Krahel, Iwona Flisiak \\ Department of Dermatology and Venereology, Medical University of Bialystok, Bialystok, Poland \\ Klinika Dermatologii i Wenerologii, Uniwersytet Medyczny w Białymstoku, Białystok, Polska \\ Dermatol Rev/Przegl Dermatol 2019, 106, 656-661 \\ DOI: https://doi.org/l0.5 I 14/dr.2019.92738
}

\author{
CORRESPONDING AUTHOR/ \\ ADRES DO KORESPONDENCJI: \\ lek. Julia Nowowiejska \\ Klinika Dermatologii \\ i Wenerologii \\ Uniwersytet Medyczny \\ w Białymstoku \\ ul. Żurawia 14 \\ 15-540 Białystok \\ tel.: +48 607130193 \\ e-mail: julia.nowowiejska94@ \\ gmail.com
}

\begin{abstract}
Introduction: Lupus tumidus is a rare type of chronic cutaneous lupus erythematosus characterized by recurring non-scarring, erythematous-oedematous skin lesions, located on sun-exposed areas.

Objective: To present two cases of patients with lupus tumidus.

Case reports: 1 . A 54-year-old woman was admitted to the Department of Dermatology due to erythematous-oedematous lesions on dorsal parts of hands, face and thighs, self-resolving. Broad evaluation for connective tissue disorders revealed no relevant abnormalities. Finally, lupus tumidus was diagnosed and hydroxychloroquine was introduced. During the therapy a breast cancer was diagnosed. 2. A 45-year-old woman presented to the Department in order to treat erythematousoedematous lesions located on the face, shoulders and upper torso that appeared 3 months earlier. The histopathological examination revealed lupus tumidus.
\end{abstract}

Conclusions: Lupus erythematosus tumidus diagnosis may pose diagnostic difficulties. Among the types of lupus erythematosus, it is distinguished by regression without scarring, significant ultraviolet hypersensitivity and rapid clinical improvement after antimalarial drugs.

\section{STRESZCZENIE}

Wprowadzenie: Postać obrzękowa jest rzadką odmianą przewlekłego skórnego tocznia rumieniowatego o nawrotowym charakterze, charakteryzującą się występowaniem niebliznowaciejących, rumieniowo-obrzękowych zmian w okolicach eksponowanych na promieniowanie słoneczne.

Cel: Opis przypadków dwóch pacjentek z postacią obrzękową tocznia rumieniowatego (LET).

Opis przypadków: 1. Kobieta 54-letnia została przyjęta do Kliniki Dermatologii z powodu nawracających od 3 lat zmian rumieniowo-obrzękowych w obrębie grzbietów rąk, twarzy i ud. Przeprowadzona kompleksowa diagnostyka w kierunku układowych chorób tkanki łącznej nie wykazała istotnych nieprawidłowości. Ostatecznie rozpoznano postać obrzękową tocznia rumieniowatego i włączono hydroksychlorochinę. W trakcie terapii zdiagnozowano u chorej raka piersi. 2. Kobieta 45-letnia została przyjęta do Kliniki w celu leczenia zmian rumieniowo-obrzękowych w obrębie twarzy, ramion oraz górnej części klatki piersiowej utrzymujących się od 3 miesięcy. W badaniu histopatologicznym obraz odpowiadał postaci obrzękowej tocznia rumieniowatego. 
Wnioski: Diagnoza postaci obrzękowej tocznia rumieniowatego. może stwarzać trudności. Wśród odmian tocznia rumieniowatego wyróżnia się brakiem bliznowacenia, wybitną nadwrażliwością na promieniowanie ultrafioletowe oraz szybką poprawą po lekach przeciwmalarycznych.

Key words: cutaneous lupus erythematosus, lupus tumidus, hydroxychloroquine.

Słowa kluczowe: skórny toczeń rumieniowaty, postać obrzękowa, hydroksychlorochina.

\section{INTRODUCTION}

E. Hoffman described lupus erythematosus tumidus (LET) for the first time in 1909 as a rare type of chronic cutaneous lupus erythematosus (CCLE) that usually has a mild, but chronic and recurrent course $[1,2]$. Some authors believe it to be a separate clinical subtype (intermittent cutaneous lupus erythematosus - ICLE), i.e. the fourth type of the lupus separated from the cutaneous acute, subacute, and chronic types [3]. It more often affects middle-aged men. The following is observed in the clinical picture: erythematous-oedematous as well as infiltrative skin lesions with no tendency to scarring that mostly cover sunexposed areas, i.e. face, neckline, upper part of the back, shoulders, and extensor surfaces of the upper limbs $[2,4-6]$. The lesions tend to recur in the same locations, and a progression into the systemic type is not usually observed, however, a conversion of LET into DLE and the other way round has been described $[2,4,7,8]$. Most often, patients do not report any subjective symptoms [2]. The diagnosis is made on the basis of dermatosis' clinical picture confirmed by a histopathological examination of a skin sample $[2,4]$. Antimalarial drugs constitute the therapy foundation [2].

\section{OBJECTIVE}

The aim of the article is to present two cases of female patients with a rare type of chronic lupus erythematosus tumidus.

\section{CASE REPORTS}

\section{Case I}

A 54-year-old woman with a history of celiac diseases was admitted to the Department of Dermatology due to erythematous-oedematous lesions on dorsal parts of hands, the face and thighs that had been

\section{WPROWADZENIE}

Postać obrzękowa tocznia rumieniowatego (lupus erythematosus tumidus - LET), po raz pierwszy opisana w 1909 roku przez E. Hoffmana, jest rzadką odmianą przewlekłego skórnego tocznia rumieniowatego (chronic cutaneous lupus erythematosus - CCLE), zwykle o łagodnym, ale przewlekłym i nawrotowym przebiegu [1, 2]. Przez część autorów bywa wyodrębniana jako oddzielny podtyp kliniczny (intermittent cutaneous lupus erythematosus - ICLE), czyli czwarta odmiana tocznia skórnego, oprócz postaci skórnej ostrej, podostrej i przewlekłej [3]. Częściej występuje u mężczyzn w średnim wieku. W obrazie klinicznym obserwuje się wykwity rumieniowo-obrzękowe, naciekowe, bez tendencji do bliznowacenia, zajmujące głównie okolice eksponowane na promieniowanie słoneczne, takie jak twarz, dekolt, górna część pleców, ramiona, powierzchnie wyprostne kończyn górnych [2, 4-6]. Zmiany mają tendencję do nawracania w tych samych miejscach i zwykle nie obserwuje się progresji do postaci układowej, natomiast opisywano konwersję LET w DLE oraz odwrotnie $[2,4,7,8]$. Pacjenci najczęściej nie zgłaszają żadnych objawów subiektywnych [2]. Rozpoznanie ustala się na podstawie obrazu klinicznego, potwierdzonego badaniem histopatologicznym wycinka skórnego [2, 4]. Podstawą terapii są leki przeciwmalaryczne [2].

\section{CEL PRACY}

Przedstawienie przypadków dwóch pacjentek z rzadką, obrzękową postacią przewlekłego skórnego tocznia rumieniowatego.

\section{OPIS PRZYPADKÓW}

\section{Przypadek I}

Kobieta 54-letnia z wywiadem celiakii została przyjęta do Kliniki Dermatologii z powodu nawracających jesienią od 3 lat zmian rumieniowo-obrzękowych w ob- 
recurring for 3 years in the autumn (figs. 1, 2). The patient reported periodical joint pain. She was hospitalized several times, also in the Department of Rheumatology, where she had comprehensive diagnostics performed for connective tissue diseases that did not show any abnormalities during upon examinations, apart from a positive low titre of antinuclear antibodies. The first histopathological examination of a skin sample taken from the dorsal area of the hand confirmed Gottron's papulae, and thus, dermatomyositis was suspected; during the second examination it was annular erythema. The image of the last skin biopsy taken from the thigh corresponded to LET. The patient was started on hydroxychloroquine at the dose of $2 \times 200 \mathrm{mg}$. Within 2 months of therapy, new skin lesions appeared gradually less often, and subsided more quickly. The patient did not report to another hospitalization due to being diagnosed with breast cancer and qualified for oncological treatment, which is currently in progress.

\section{Case 2}

A 45-year-old woman presented to the Department in order to treat erythematous-oedematous skin

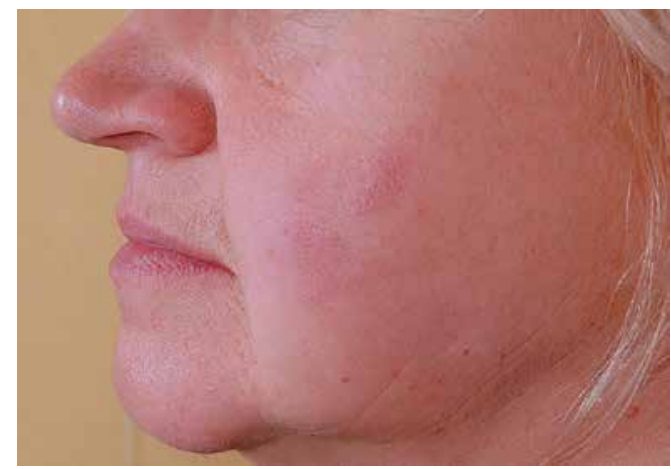

Figure I. Erythematous-oedematous lesions on the left cheek in patient I

Rycina I. Zmiany rumieniowo-obrzękowe na policzku lewym u pacjentki I.

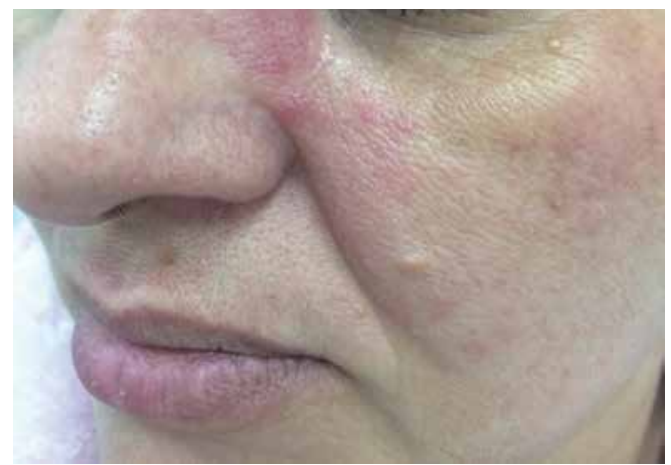

Figure 3. Erythematous-oedematous lesions on the nose and left cheek in patient 2

Rycina 3. Zmiany rumieniowo-obrzękowe na nosie i lewym policzku u pacjentki 2. rębie skóry grzbietów rąk, twarzy i ud (ryc. 1, 2). Pacjentka zgłaszała okresowo bóle stawów. Wcześniej była hospitalizowana kilkukrotnie, również w Klinice Reumatologii, gdzie przeprowadzono kompleksową diagnostykę $\mathrm{w}$ kierunku chorób układowych tkanki łącznej. Nie stwierdzono istotnych nieprawidłowości w badaniach, poza dodatnim, niskim mianem przeciwciał przeciwjądrowych. W pierwszym badaniu histopatologicznym wycinka ze skóry grzbietu ręki stwierdzono grudki Gottrona i wysunięto podejrzenie zapalenia skórno-mięśniowego, natomiast w kolejnym - rumienia obrączkowatego. W ostatnim wycinku zmiany ze skóry uda obraz odpowiadał LET. Rozpoczęto leczenie hydroksychlorochiną $\mathrm{w}$ dawce $2 \times 200 \mathrm{mg}$. $\mathrm{W}$ czasie 2 miesięcy terapii obserwowano stopniowo rzadsze pojawianie się nowych zmian skórnych i jednocześnie ich szybsze ustępowanie. Pacjentka nie zgłosiła się na ponowną hospitalizację z powodu wykrycia $\mathrm{u}$ niej raka piersi i kwalifikacji do leczenia onkologicznego, które jest w toku.

\section{Przypadek 2}

Kobieta 45-letnia została przyjęta do Kliniki w celu leczenia zmian skórnych w obrębie twarzy, dekoltu,

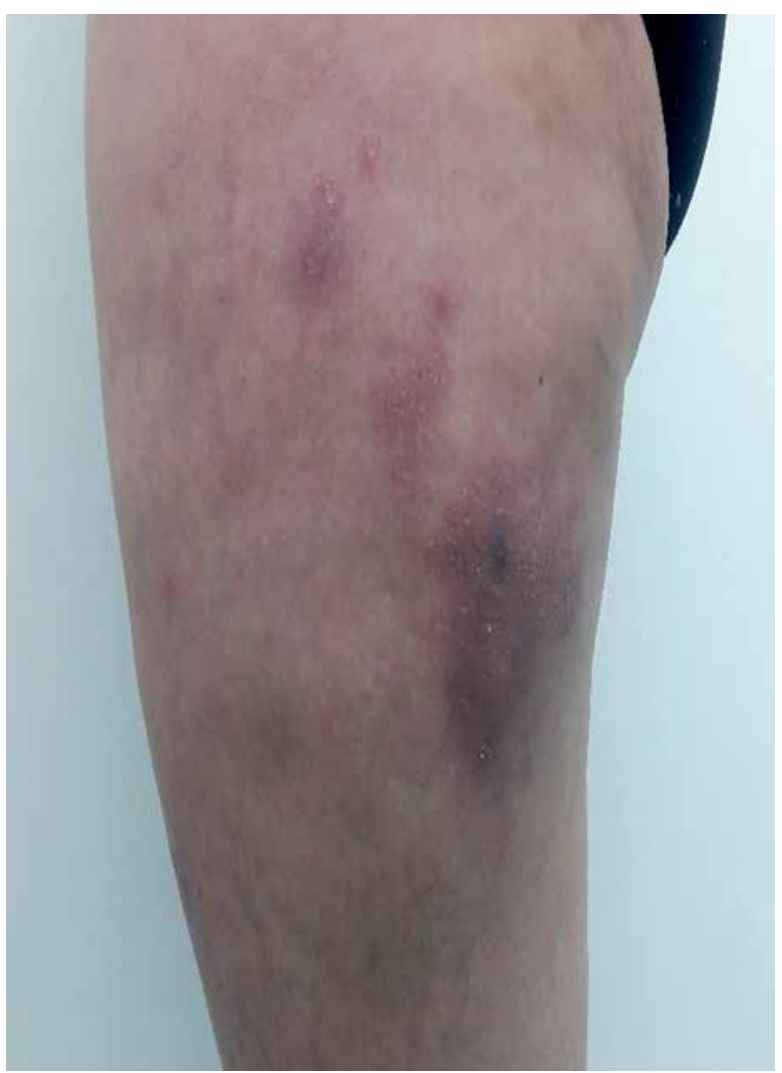

Figure 2. Erythematous-oedematous lesions on the left thigh in patient I

Rycina 2. Zmiany rumieniowo-obrzękowe na skórze lewego uda u pacjentki I. 
lesions found on the face, neckline, shoulders and upper torso that appeared 6 months earlier, and initially involved the bridge of nose (fig. 3). The lesions did not cause subjective pain. Patient's medical history included exposure to sawdust at work. Antihistamine drugs, ointment with mupirocin, and oral cefuroxime were used on an outpatient basis, however, there no was clinical improvement. During the stay at the Department, tests for systemic lupus erythematosus were performed: ANA3 panel (antinuclear antibodies), negative, ANA titre, C3, C4 complement system - normal; for sarcoidosis: angiotensin converting enzyme activity and calcium concentration - normal. A skin lesion sample was taken for histopathological examination: microscopic image corresponded to LET. The patient was started on hydroxychloroquine; clinical remission was achieved after 3 months, however, due to the fact that the drug was unavailable, the patient discontinued it. During the following 2 months, skin lesions reappeared. The therapy was reinitiated, this time with chloroquine, $1 \times 250 \mathrm{mg} /$ day in 10-day cycles, and the skin lesions disappeared completely within 3 months. In the diagnostics of both patients, phototests were not routinely available.

\section{DISCUSSION}

In 2000 Kuhn et al. suggested diagnostic criteria for oedematous CCLE: clinical and histopathological picture, appearance of new lesions after UVA and/or UVB exposure, and fast as well as effective response to antimalarial drugs [4]. Clinical criteria include the presence of thickened erythematous plaques with smooth oedematous surface in the areas exposed to sun that disappears without scarring. Histological criteria include, first and foremost, perivascular and periadnexal lymphocytic infiltration, deposits of mucin in the dermis, and no disorders within the dermal-epidermal junction and epidermis that are typical for other CCLE forms [2, 4, 5, 8]. Hypersensitivity to sun radiation is observed in this form of lupus - the highest among all CCLE types - that occurs in about $70 \%$ of LET-patients $[2,4,8]$. Characteristically, the time between the sun exposure and the appearance of skin lesions is relatively long, depending on the sources from 1 up to even 3 weeks, and consequently, patient often do not associate lesions with UV radiation $[2,4,9]$. Antimalarial drugs result in a fast improvement and disappearance of skin lesions, usually within a couple of weeks; the difference in efficacy of chloroquine and hydroxychloroquine was not confirmed $[8,10]$. In both presented patients, a good response to antimalarial drugs and complete clinical remission were observed. It is suggested that there exists a connection between LET and smoking, ramion oraz górnej części klatki piersiowej w postaci licznych, rozsianych ognisk rumieniowo-obrzękowych, które pojawiły się pół roku wcześniej, początkowo w okolicy nasady nosa (ryc. 3). Zmiany nie wywoływały dolegliwości subiektywnych. W wywiadzie stwierdzono ekspozycję na trociny w zakładzie pracy. Ambulatoryjnie stosowano leki przeciwhistaminowe, maść z mupirocyną oraz cefuroksym doustnie, nie uzyskując poprawy klinicznej. W trakcie pobytu w Klinice wykonano badania w kierunku postaci układowej tocznia rumieniowatego: panel ANA3 (anitnuclear antibodies przeciwciała przeciwjądrowe) ujemny, miano ANA, składowe C3, C4 dopełniacza - w normie, w kierunku sarkoidozy: aktywność konwertazy angiotensyny i stężenie wapnia - w normie. Pobrano wycinek ze zmiany skórnej do badania histopatologicznego - obraz mikroskopowy odpowiadał LET. Włączono hydroksychlorochinę, po 3 miesiącach uzyskano remisję kliniczną, jednak ze względu na brak dostępności leku pacjentka zaprzestała jego stosowania. W czasie kolejnych 2 miesięcy nastąpił nawrót zmian skórnych. Ponownie rozpoczęto terapię, tym razem chlorochiną $1 \times 250 \mathrm{mg} /$ dobę w cyklach 10-dniowych. Uzyskano całkowite ustąpienie wykwitów w czasie 3 miesięcy. W diagnostyce obu pacjentek nie były rutynowo dostępne próby świetlne.

\section{OMÓWIENIE}

W 2000 roku Kuhn i wsp. zaproponowali kryteria diagnostyczne dla postaci obrzękowej CCLE: obraz kliniczny i histopatologiczny, pojawianie się nowych zmian po ekspozycji na promieniowanie UVA i/lub UVB oraz szybka i skuteczna odpowiedź na leki przeciwmalaryczne [4]. Kryterium kliniczne to obecność pogrubiałych, rumieniowych blaszek o gładkiej, obrzękniętej powierzchni w okolicach eksponowanych na słońce, ustępujących bez pozostawienia blizn. Kryteria histologiczne obejmują przede wszystkim okołonaczyniowy i okołoprzydatkowy naciek limfocytarny, odkładanie się złogów mucyny w skórze właściwej oraz brak zaburzeń w obrębie połączenia skórno-naskórkowego i w naskórku typowych dla innych postaci CCLE $[2,4,5,8]$. W tej postaci tocznia obserwuje się wybitną nadwrażliwość na promieniowanie słoneczne, największą spośród wszystkich odmian CCLE, występującą u ok. 70\% chorych z LET $[2,4$, 8]. Charakterystyczne jest to, że czas pomiędzy ekspozycją na słońce a momentem pojawienia się zmian skórnych jest dość długi, w zależności od źródeł od 1 do nawet 3 tygodni, co często powoduje, że pacjenci nie wiążą wystąpienia wykwitów z promieniowaniem UV [2, 4, 9]. Leki przeciwmalaryczne powodują szybką poprawę i ustąpienie zmian skórnych, zwykle w ciągu kilku tygodni, przy czym nie stwierdza się różnicy w skuteczności pomiędzy chlorochiną a hydroksychlorochiną $[8,10]$. $\mathrm{U}$ obu przedstawionych pacjentek obserwowano dobrą 
which additionally worsens the efficacy of antimalarial drugs [6]. One of the described patients did not smoke, the other one stopped 3 years earlier. In LETpatients, ANAs are negative, and our patients were not different; according to Kuhn et al., they are confirmed only in $10 \%$ of patients $[4,11]$. The literature includes contradictory reports regarding the connection between lupus erythematosus and neoplasms. Some studies showed significantly more frequent occurrence of various neoplasms in CLE-patients as compared with the control group - especially within the respiratory tract and cheek mucous membranes, and lymphoma, however, not leukaemia or melanoma. Simultaneously, in other reports did not confirm such a tendency in a group of patients with lupus [12]. One of the discussed patients was diagnosed with breast cancer right after commencing a LET therapy. There are no similar cases in the literature, and thus, it is difficult to determine explicitly whether a concurrence of LET and breast cancer is a significant link or a coincidence. Final LET diagnosis is often delayed due to its diverse clinical picture, and no subjective or systemic symptoms and signs [9]. So far, the incidence of the disease was both underestimated and underdiagnosed. The diagnosis should always be based on a clinical picture confirmed by a histopathological examination of a skin sample [9]. Differential diagnostics should include other CCLE types, multiform light eruptions, reticular mucinosis, and pseudo-lymphoma conditions, among others $[2,4]$. In LET treatment the following drugs of choice are recommended: antimalarial drugs, topical glucocorticosteroids, and sunscreens $[2,5]$. Some patients require systemic use of glucocorticosteroids and immunosuppressive drugs [5].

\section{CONCLUSIONS}

Lupus erythematosus tumidus is rare and may more diagnostic challenges. It differs from other types of lupus erythematosus with remission without scarring, special hypersensitivity to sun radiation, and fast improvements after antimalarial drugs. The connection between cutaneous lupus and cancers is possible, however, it requires further monitoring.

\section{CONFLICT OF INTEREST}

The authors declare no conflict of interest. odpowiedź na leki przeciwmalaryczne i pełną remisję kliniczną. Postuluje się również związek LET z paleniem papierosów, które może zmniejszać skuteczność leków przeciwmalarycznych [6]. Jedna z opisywanych pacjentek była niepaląca, druga zaprzestała palenia przed 3 laty. U pacjentów z LET zwykle ANA są ujemne, podobnie jak u naszych pacjentek, wg Kuhn i wsp. stwierdza się je zaledwie u $10 \%$ chorych $[4,11]$. $\mathrm{W}$ piśmiennictwie istnieją sprzeczne doniesienia dotyczące związku tocznia skórnego z nowotworami. W niektórych badaniach stwierdzono istotnie częstsze występowanie różnych nowotworów u pacjentów z CLE w porównaniu z grupą kontrolną - zwłaszcza w obrębie dróg oddechowych i błon śluzowych policzka oraz chłoniaków, jednak nie białaczek czy czerniaka. Jednocześnie w innych doniesieniach nie stwierdzono takiej tendencji u pacjentów z toczniem skórnym [12]. $\mathrm{U}$ jednej z omawianych pacjentek tuż po rozpoczęciu terapii LET zdiagnozowano raka piersi. W piśmiennictwie nie ma opisów podobnych przypadków, dlatego trudno jest jednoznacznie stwierdzić, czy współistnienie LET $\mathrm{z}$ rakiem piersi jest istotnym powiązaniem czy koincydencją. Ostateczne rozpoznanie LET bywa często opóźnione ze względu na różnorodny obraz kliniczny, brak objawów subiektywnych lub układowych [9]. Do tej pory częstość występowania LET była niedoszacowana, a sama choroba niedodiagnozowana. Rozpoznanie powinno zawsze opierać się na obrazie klinicznym, następnie potwierdzonym badaniem histopatologicznym wycinka skóry [9]. W diagnostyce różnicowej należy uwzględnić m.in. inne odmiany CCLE, wielopostaciowe osutki świetlne, siatkowatą mucynozę i stany rzekomochłoniakowe [2, 4]. W leczeniu LET zaleca się z wyboru leki przeciwmalaryczne, glikokortykosteroidy miejscowe, a także stosowanie kremów z filtrem przeciwsłonecznym $[2,5]$. Nieliczni pacjenci wymagją ogólnego stosowania glikokortykosteroidów i leków immunosupresyjnych [5].

\section{WNIOSKI}

Postać obrzękowa tocznia rumieniowatego występuje rzadko i może stwarzać trudności diagnostyczne. Od innych odmian tocznia rumieniowatego odróżnia się ustępowaniem bez bliznowacenia, wybitną nadwrażliwością na promieniowanie słoneczne i szybką poprawą po lekach przeciwmalarycznych. Związek postaci skórnej tocznia z nowotworami jest możliwy, ale wymaga dalszych obserwacji.

\section{KONFLIKT INTERESÓW}

Autorzy nie zgłaszają konfliktu interesów. 


\section{References}

\section{Piśmiennictwo}

1. Hoffman E.: Isolierter lupus erythematosus tumidus der gesichtshaut. Derm Zeitschr 1909, 16, 159-160.

2. Chylicka J., Szczerkowska-Dobosz A., Gwiazdowska A., Sokołowska-Wojdyło M.: Lupus erythematosus tumidus - rzadka odmiana przewlekłej skórnej postaci tocznia rumieniowatego. Przegl Dermatol 2011, 98, 335-339.

3. Kuhn A., Landmann A.: The classification and diagnosis of cutaneous lupus erythematosus. J Autoimmun 2014, 48-49, 14-19.

4. Kuhn A., Richter-Hintz D., Oslislo C., Ruzicka T., Megahed M., Lehmann P.: Lupus erythematosus tumidus. A neglected subset of cutaneous lupus erythematosus: report of 40 cases. Arch Dermatol 2000, 136, 1033-1041.

5. Stitt R., Fernelius C., Roberts J., Denunzio T., Arora N.S.: Lupus erythematosus tumidus: a unique disease entity. Hawaii J Med Public Health 2014, 73, 18-21.

6. Gallitano S.M., Haskin A.: Lupus erythematosus tumidus: a case and discussion of a rare enitity in black patients. JAAD Case Rep 2016, 2, 488-490

7. Jolly M., Laumann A.E., Shea C.R., Utset T.O.: Lupus erythematosus tumidus in systemic lupus erythematosus: novel association and possible role of early treatment in prevention of discoid lupus erythematosus. Lupus 2004, 13, 64-69.

8. Chen X., Wang S., Li L.: A case report of lupus erythematosus tumidus converted from discoud lupus erythematosus. Medicine 2018, 97, e0375.

9. Bousquet Muylaert B.P., Braga B.B., Esteves E.B., Garbelini L.E., Michalany A.O., Oliveira F.J.: Lupus tumidus: a report of two cases. An Bras Dermatol 2016, 91, 87-89.

10. Kreuter A., Gaifullina R., Tigges C., Kirschke J., Altmeyer P., Gambichler T., et al.: Lupus erythematosus tumidus: response to antimalarial treatment in 36 patients with emphasis on smoking. Arch Dermatol 2009, 145, 244-248.

11. Rodriguez-Caruncho C., Bielsa I., Fernández-Figueras M.T., Roca J., Carrascosa J.M., Ferrandiz C.: Lupus erythematosus tumidus: a clinical and histological study of 25 cases. Lupus 2015, 24, 751-755.

12. Singh A.G., Crowson C.S., Singh S., Davis M.D., Maradit-Kremers H., Matteson E.L., et al.: Cancer risk in cutaneous lupus erythematosus: a population-based cohort study. Rheumatology 2016, 55, 2009-2013.

Received: 2.03 .2019

Accepted: 7.08 .2019

Otrzymano: 2.03.2019 r.

Zaakceptowano: 7.08.2019 r.

How to cite this article

Nowowiejska J., Baran A., Krahel J.A., Flisiak I.: Lupus tumidus - two cases reports. Dermatol Rev/Przegl Dermatol 2019, 106, 656-661. DOI: https://doi.org/10.5114/dr.2019.92738. 